\title{
REVIEW
}

UDC 616.441.-006.6-092.9:615.252

doi: https://doi.org/10.15407/ubj90.05.005

\section{BIOCHEMICAL ASPECTS OF THE COMBINED USE OF TAXANES, IRRADIATION AND OTHER ANTINEOPLASTIC AGENTS FOR THE TREATMENT OF ANAPLASTIC THYROID CARCINOMA}

\author{
V. M. PUSHKAREV , O. I. KOVZUN, V. V. PUSHKAREV, \\ B. B. GUDA, M. D. TRONKO \\ SI V. P. Komisarenko Institute of Endocrinology and Metabolism, \\ NAMS of Ukraine, Kyiv; \\ e-mail: pushkarev.vm@gmail.com
}

The review summarizes the results of the cycle of own research and literature data on biochemical mechanisms of combined action of taxanes with $\gamma$-irradiation and other antineoplastic agents on one of the most aggressive types of human cancer - anaplastic thyroid carcinoma. Antagonistic interplay between taxanes and irradiation at the level of apoptotic mechanisms and regulators of the cell cycle are discussed. The effectiveness and prospects of using low concentrations of taxanes and low doses of fractional $\gamma$-irradiation are substantiated. Attention is paid to the role of inflammation and its key factor $-N F-\kappa B$ in the genesis of thyroid carcinomas and their treatment. Directions for further research are outlined.

Ke ywords: anaplastic thyroid carcinoma, taxanes, $\gamma$-irradiation, cell cycle, roscovitine, $N F-\kappa B$, apoptosis.

\section{Anaplastic thyroid carcinoma}

The Chernobyl accident led to the increase in thyroid cancer incidence in Ukraine. There is also a rise in anaplastic thyroid carcinoma (ATC) that originates from the thyroid follicular cells. This type of solid tumors is a relatively rare (1-5\% of all malignant thyroid tumors) but one of the most aggressive types of human cancer with an extremely poor prognosis and almost $100 \%$ mortality due to uncontrolled systemic metastasis [1-3].

ATC is highly resistant to conventional cancer therapies. As a result, $90 \%$ of patients with anaplastic thyroid carcinoma die within 6 months after diagnosis (the median survival rate is just 4 months and has not increased over the past 50 years) and this type of cancer accounts for more than $50 \%$ of all thyroid-cancer-related deaths annually [4].

In contrast to differentiated thyroid cancer (DTC) cells (papillary thyroid carcinoma - PTC, and follicular thyroid carcinoma - FTC) ATC cells do not retain any of the biological features or functions of normal follicular cells, such as iodine uptake, thyroglobulin synthesis and TSH dependence [5].

ATC often originates in an abnormal thyroid gland. For example, a chronic goiter has been reported in more than $80 \%$ of patients, and DTC is associated with ATC in some patients [5]. Chronic autoimmune thyroiditis (AIT) is also accompanied by the malignant transformation of thyroid tissue [6]. Progression to ATC has been attributed to a multistep dedifferentiation process that starts in a pre-existing DTC lesion (Fig. 1). This hypothesis is supported by the evidence that B-Raf and RAS mutations [7] (which occur in approximately 60 and $12 \%$ of PTC, respectively) can be found at a higher frequency in ATC that contain the areas of DTC [8]. Therefore, the process of dedifferentiation is probably caused by the stepwise accumulation of somatic

(C) 2018 Pushkarev V. M. et al. This is an open-access article distributed under the terms of the Creative Commons Attribution License, which permits unrestricted use, distribution, and reproduction in any medium, provided the original author and source are credited. 
mutations in cancer-related genes, particularly TP53 and genes that encode proteins involved in the PI3K/ Akt pathway [9]. But the presence of pure ATC cases supports the idea of a direct normal follicular cell transformation to a completely undifferentiated cell [5].

In multistep carcinogenesis, ATC cells are generated directly from thyrocytes by multiple damage to their genomes and the emerging ability of unlimited proliferation, invasion, and metastasis. However, since thyrocytes rarely proliferate in adults, it seems unlikely that after a few divisions they acquire all of these malignant features. From the molecular point of view, the main criticism of the classical model of multistep carcinogenesis is that anaplastic carcinomas, which are described to be derived from differentiated carcinomas by accumulated mutations, do not undergo genetic alterations often observed in differentiated carcinomas. RET/ PTC and PAX8/PPAR $\gamma$ rearrangements are observed in a high prevalence of differentiated carcinomas but they are not detected in anaplastic carcinomas [10].

The cancer stem-like cell model suggests that a small number of cells within a tumor, known as CSC, are responsible for resistance to chemotherapy and radiation therapy, as well as for recurrent and metastatic disease. This model that may explain the aggressive behavior of some thyroid cancers, such as anaplastic cancer, the development of recurrent disease and metastases after surgery, and the resistance of some thyroid cancers to chemotherapy and radiation therapy, involves the existence of CSC (Fig. 1) [11, 12]. The model agrees with the fetal cell carcinogenesis of the thyroid, which suggests that stem cells give rise directly to well-differentiated and undifferentiated thyroid carcinomas [13].

ATC can be divided into B-Raf or RAS molecular groups, or neither B-Raf nor RAS tumors with recurrent mutations in genes such as $N F 1, M T O R$ and the MutL-homologue family of DNA mismatch repair genes, which result in a hypermutator phenotype $[14,15]$.

B-Raf V600E and RAS mutations remain the main drivers in aggressive thyroid carcinoma, but ATC gains additional mutations.

TP53 mutation (cumulative mutation rate 59\%), TERT (telomerase reverse transcriptase) promoter mutation (up to 73\%), EIF1AX (X-linked eukaryotic translation initiation factor $1 \mathrm{~A}$ ) mutation as well as frequent alterations in PIK3CA/AKT/mTOR path-

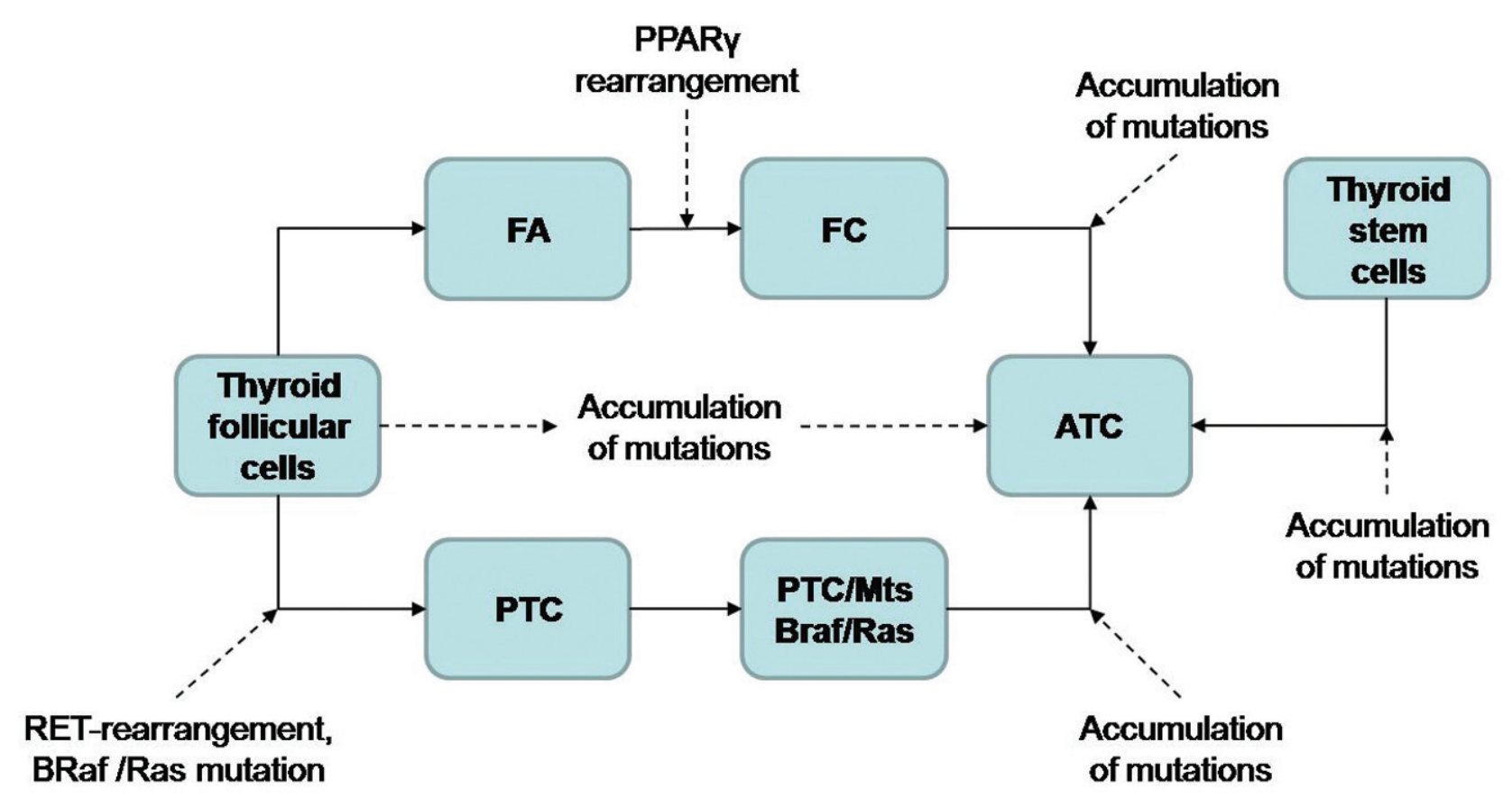

Fig.1. Main hypothesis on ATC origin. 1. Direct malignization of thyroid follicular cells (the least likely scenario due to low proliferative activity of thyrocytes). 2. Further dedifferentiation of DTC (PTC and FTC) bearing B-Raf and RAS mutations but without RET/PTC and PAX8/PPAR $\gamma$ rearrangements. 3. Transformation of stem cells into cancer stem cells giving rise to ATC 
way (PIK3CA, PTEN, PIK3C2G, PIK3CG, PIK3C3, PIK3R1, PIK3R2, AKT3, TSC1, TSC2, mTOR), SWISNF nucleosome remodeling complex (ARID1A, ARID1B, ARID2, ARID5B, SMARCB1, PBRM1, $A T R X$ ), DNA mismatch repair genes (MSH2, MSH6, MLH1), and histone methyltransferases (KMT2A, $K M T 2 C, K M T 2 D, S E T D 2)$ are present at a higher frequency in advanced thyroid carcinomas [16]. EIF1AX, a gene related to eukaryotic translation initiation factor, is associated with progression from FTC to ATC, as EIF1AX mutations are closely associated with RAS mutations. Mutations in WNT signaling pathway, include CTNNB1 ( $\beta$-catenin), $A P C$, and $A X I N 1$, with lower mutation frequency of 3 to $4.5 \%$ in ATC $[14,17]$.

Other novel molecular alterations have been identified in ATC, such as mutations in the gene that encodes isocitrate dehydrogenase 1 (IDH1) and two point mutations in the ALK gene, Leu1198Phe (c.3592C $>$ T) and Gly1201Glu (c.3602G $>$ A) [5]. However, their role in ATC tumorigenesis is unclear.

Sixteen cancer-related genes, not typically identified as drivers of thyroid malignancy, were found to be present among the studied tumors. Some of these mutations were present in multiple samples and are strongly correlated with non-thyroid malignancies, such as $N F 1, m T O R, E R B B 2, D A X X, M L L 2$, and NOTCH2 [14].

Copy number alternations (CNAs) are common and widespread in advanced thyroid carcinomas, particularly ATC. Most CNAs detected in advanced thyroid cancers are related to specific tumor types and distinct driver gene mutations [17].

The clinical management of ATC according to recent American Thyroid Association guidelines requires surgery, radiotherapy and chemotherapy [5]. Activation of mitogenic and angiogenic signaling pathways occurs in ATC, and preclinical models have shown that inhibition of key kinase steps in these pathways can have antitumor effects. Now, in addition to conventional therapies, novel molecular targeted therapies are promising. These drugs are often multiple receptor tyrosine kinase inhibitors, several of which have been tested in phase II and phase III of clinical trials, with modestly encouraging results [18].

But no unified ATC treatment improving overall survival has been established.

Now hundreds of new approaches to cancer treatment have been developed. However, in clinics, as to the last century, three main methods are used: surgery followed by chemotherapy and irradiation. Therefore, the task of researchers is to increase the effectiveness of the latter two methods while reducing their toxicity to the body.

\section{Action of taxanes}

Taxanes are the most potent anticancer drugs introduced into medical practice during the last several decades. They have been used for treatment of certain types of human malignancies such as ovarian, breast, lung, and head and neck cancer with relative success. Trials have been performed to expand the list of tumors that can be treated with paclitaxel (Ptx) and docetaxel (Dtx), including human thyroid cancers $[19,20]$. The understanding of the molecular mechanisms of a chemotherapeutic agent action in cancer and normal cells is indispensable for planning the evidence based clinical applications.

All ATC cell lines we tested were sensitive to Ptx and Dtx, although to a different extent. In primary thyrocytes the drug displayed substantially lower cytotoxicity (Fig. 2). In thyroid cancer cells, Ptx induced changes, characteristic to apoptosis such as poly (ADP-ribose) polymerase and procaspase cleavage and alteration of membrane asymmetry, only within a narrow concentration range, from 1 to $30 \mathrm{nM}$. Maximum was observed at $10-25 \mathrm{nM}$ and further increase of Ptx concentration to $100 \mathrm{nM}$ resulted in a reduction of caspases activation [19]. Low Ptx concentrations caused changes in the cell cycle that are typical of apoptosis without cell cycle arrest. At higher concentrations, other form(s) of cell death possibly associated with mitochondrial collapse was/were observed. At Ptx concentration of $100 \mathrm{nM}$, most cells lost their mitochondrial membrane potential [21].

In ATC cells low doses of Ptx enhanced Bcl-2 phosphorylation and led to its degradation observed on the background of increasing Bax level and accumulation of survivin and proteins-inhibitors of apoptosis (cIAP1/2, XIAP).

According to flow cytometry data, low Ptx concentrations induced apoptosis in vast majority of ATC cells. We observed apoptosis in $20 \%$ of the KTC-2 cells at Ptx concentrations as low as $1 \mathrm{nM}$. At $15 \mathrm{nM}$ of the drug, the proportion of apoptotic cells increased to $83 \%$. $50 \mathrm{nM}$ of Ptx caused apoptotic and possibly other forms of death in almost entire cell population. An increased level of subG1 cells is paralleled by massive apoptosis suggesting that namely this form of cell death is the predominant 


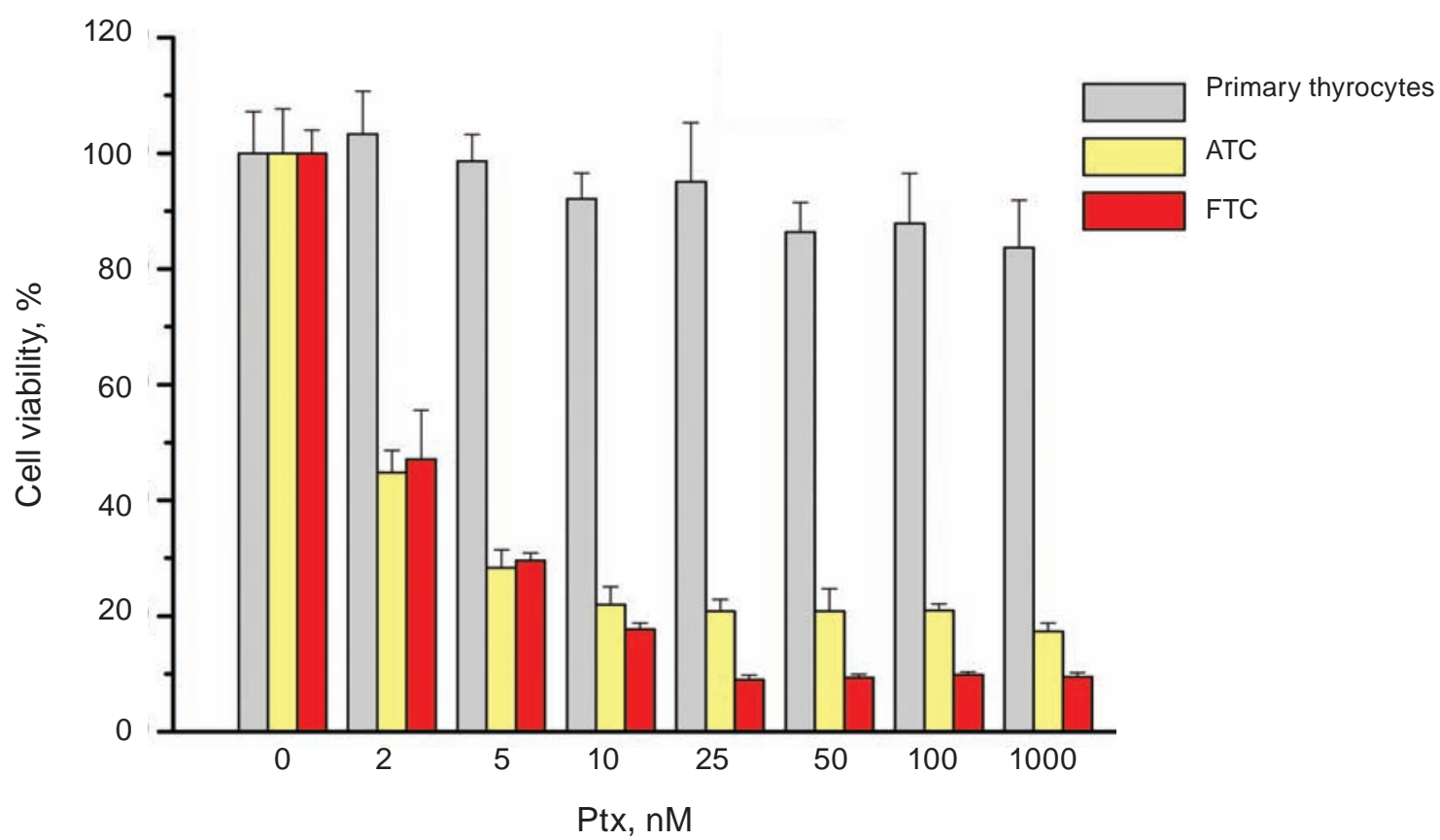

Fig. 2. Comparison of Ptx action on normal and cancer cells of thyroid. The figure shows the effective concentrations of Ptx for FTC (FRO cell line) and ATC (KTC-2). It can be seen that already a concentration of $2 \mathrm{nM}$ is effective and starting from a concentration of $25 \mathrm{~nm}$ the cell viability does not change. Normal thyrocytes proved to be more resistant to taxanes due to low proliferative activity. The differences from control (without Ptx) and differences between normal and cancer cells are significant starting at a concentration of $2 n M(P<0.01)$. Differences between ATC and FTC cells are significant starting at a concentration of $25 n M$ $(P<0.05)$

mechanism of ATC cell elimination at low Ptx concentrations. Higher drug doses starting from $50 \mathrm{nM}$ arrested cell cycle in G2/M phase. Upon Ptx action, the increase in the number of cells with manifestations of accelerated senescence was insignificant [21].

C-jun-NH2 terminal kinase (JNK) and to a lesser extent p38MAPK activation was essential for the apoptosis in KTC-2 and ARO cells, whereas Raf/ MEK/ERK, phosphatidylinositol-4,5-bisphosphate 3-kinase (PI3K)/Akt and NF- $\mathrm{BB}$ were likely to comprise main survival mechanisms [19, 22].

To increase Ptx efficacy, it is essential to understand fine biochemical changes induced by the drug in thyroid cancer cells. Ptx is well known to cause microtubules hyperpolymerization that in turn results in cell cycle alterations/arrest [23, 24], but the detailed mechanisms of its effects on cell cycle machinery are still unclear.

Low doses of Ptx, that cause apoptosis, enhanced retinoblastoma protein (pRb) phosphorylation, decreased the expression of cyclin-dependent kinase inhibitors $\mathrm{p} 27^{\mathrm{KIP} 1}$ and $\mathrm{p} 21^{\mathrm{WAF} 1}$, activated phosphatase Cdc25C (dephosphorylation of Ser216), which in turn activated Cdk1 by removing inhibitory phosphate at 15 tyrosine residues, significantly increased in Cdk1 cofactor cyclin B1 expression and potentiated the accumulation of phosphorylated p53 and the peptidyl-prolyl cis-/trans-isomerase Pin1. Thus, low concentrations of the drug cause activation of mitogenic cell cycle factors in KTC-2 cells [25].

High Ptx doses $(>50 \mathrm{nM})$ that cause cell cycle arrest and necrosis-like cell death drastically decreased Pin1 level in all studied cell lines. Druginduced Pin1 accumulation could probably facilitate cell cycle transition and in parallel contribute to apoptosis via the p53/p73-dependent mechanism. A decrease of Pin1 levels at higher doses of Ptx may be a reason for G2/M cell cycle arrest and necrosis [25].

\section{Combined action of taxanes and other agents}

\subsection{Ionizing radiation}

Since Ptx mainly affects the microtubules thus blocking cell division, usage of additional agents that 
would damage DNA in tumor cells to cause genotoxic stress is a plausible modality. One of the agents widely used in combination with chemotherapy, is the ionizing radiation (IR). It is believed that Ptx enhances tumor cell radio sensitivity [26, 27], possibly due to cell cycle arrest at G2/M phase, in which the cells are considered to be more sensitive to radiation [27].

The data obtained in the in vivo experiments showed that IR significantly inhibited but did not abrogate xenograft tumor growth. Ptx effect was stronger, and the combination therapy with Ptx and IR led to the decrease of tumor volume to $0-0.3 \%$ of the control [28]. Thus, IR enhanced the effect of Ptx, and after 20 days of treatment, tumors regressed. It seems that a combination of chemotherapy and DNA-damaging agents may be effective for ATC treatment. Therefore it was important to elucidate the biochemical mechanisms of combined action of Ptx and IR in ATC cells.

Study of the IR action on the KTC-2 cell survival showed that high (5-20 Gy) doses of $\gamma$-irradiation had almost no evident effect in the first $24 \mathrm{~h}$. A significantly lower cell survival was observed only at a dose of $20 \mathrm{~Gy}$. It is noteworthy that in the first $24 \mathrm{~h}$ low doses of radiation - 0.5-2 Gy were more effective than higher doses. In 48 and $72 \mathrm{~h}$ after irradiation (5-20 Gy) the dose-dependent decrease in cell survival was observed. Anaplastic cancer cell line with wild-type TP53 (KTC-2) was more sensitive to radiation exposure than cell lines with inactive gene (ARO) [29].

Study of the combined action of Ptx and IR on cell survival showed that the final effect was dependent on Ptx concentration. Data obtained at $1 \mathrm{nM}$, $5 \mathrm{nM}$ and $25 \mathrm{nM}$ of Ptx. At $5 \mathrm{nM}$ of Ptx the cytotoxic effect of IR at a dose of 5Gy was insignificant. Thus, it may be noted that at this concentration Ptx exhibits clear radioprotective effect [29]. A weak radioprotective effect of $\mathrm{Ptx}$ was also noted earlier [30].

Both proapoptotic and antiapoptotic factors activation under the joint action of IR (5 Gy) and Ptx $(25 \mathrm{nM})$ was observed. Ptx and $\gamma$-irradiation separately essentially increased the expression of proapoptotic protein Bax in KTC-2 cells. However, both agents combined reduced Bax content in the cells compared with the action of Ptx and IR as single agents. In addition, the enhanced expression of apoptosis inhibitor survivin under combined action of Ptx and IR was observed. The decrease of Bax and the increase of survivin expression may indicate the attenuation of apoptotic process in tumor cells [29].

Further studies showed that IR dose of $5 \mathrm{~Gy}$ did not activate caspase- 3 , and caspase- 8 , while $25 \mathrm{nM}$ of Ptx activated caspase- 8 and, especially, the main effector caspase-3. A combination of Ptx and IR increased activation of both caspases. Besides, the enhanced phosphorylation of antiapoptotic protein Bcl-2 under the combined action of Ptx and IR was observed.

IR itself does not essentially activate apoptotic mechanisms in KTC-2 cells. There was no activation of caspase- 3 and PARP cleavage. The effect of Ptx was noticeably stronger. The amount of activated caspase- 3 increased significantly and that of intact PARP decreased more than 20 times. This effect was abolished in the presence of JNK inhibitor indicating the participation of this protein kinase in Ptx-dependent apoptosis [29].

Since Ptx and IR affect the cell cycle, it was important to determine the status of main cycle regulators upon the action of these agents, both individually and combined. The $\gamma$-rays (5 Gy) markedly increased the phosphorylation of Ser15 and stabilization of p53 tumor suppressor in KTC-2 cells [29]. Ptx at $25 \mathrm{nM}$ concentration, which induced the classical apoptosis in all ATC cells [19], also increased the phosphorylation of $\mathrm{p} 53$, but to a lesser extent, compared with IR. But in the presence of Ptx, IRdependent phosphorylation of p53 was significantly decreased [29]. Accumulation of p53 causes transactivation of the proapoptotic genes, particularly of Bax, which is one of the key factors in the mitochondrial pathway of apoptosis [31].

The same pattern of IR and Ptx actions is characteristic of phosphorylation of non-receptor tyrosine kinase c-Abl [29], which stimulates the accumulation of active p53 due to its stabilization [32, 33] and participates in Ptx-dependent processes: apoptosis induction and cell cycle arrest at G2/M phase [34]. The combined action of IR and Ptx almost completely abolishes the tyrosine kinase phosphorylation at Thr735, which is phosphorylated upon stress stimulation [29].

It is known that ATM (ataxia telangiectasia mutated) kinase and checkpoint kinase 2 (CHK2) mediate the effects of $\gamma$-irradiation on $\mathrm{p} 53$ activation [35]. Ptx and especially IR activate CHK2. In the presence of both agents, as in the case of p53, Bax and c-Abl, CHK2 phosphorylation and thus, activation was significantly decreased as compared to IR effect individually [29]. 
The action of IR caused inactivation of another tumor suppressor - retinoblastoma protein (pRb), which occurred through cascade phosphorylation of pRb by cyclin/CDK complexes and in turn resulted in the release of E2F family of transcription factors [36]. The joint effect of both agents led to a significant attenuation of IR effect in KTC-2 and FRO cells. Thereby, IR by itself can exhibit a certain mitogenic effect by stimulating the cell cycle regulators involved in transition at the G1/S phase and initiation of DNA synthesis [29]. As was shown in previous section, Ptx also displays some mitogenic properties and this effect, apparently, is mediated by similar signaling mechanisms [25].

Summing up these data, it can be noted that Ptx and IR, in particular, induce activation of cell cycle regulatory proteins - p53, c-Abl, CHK2, which, depending on the strength of external stress, determine the direction of cell processes and cell fate. Another important point is the inhibition of their activation under the simultaneous action of Ptx and IR. One can assume that the key factor, which determined this inhibition, was c-Abl activity [29]. c-Abl - a ubiquitously expressed non-receptor tyrosine kinase, which is activated in response to a variety of signals including the DNA damage and plays the important role in IR-induced apoptosis and DNA repair [37]. According to the latest data, c-Abl not only stabilizes and activates p53, but is necessary for full activation of upstream transducers - ATM and ATR [37], which in turn phosphorylate p53, CHK1, CHK2, BRCA1 and c-Abl itself.

Thus, IR and Ptx are in antagonistic relations regarding phosphorylation and expression of several proteins that mediate the effects of both agents in tumor cells. Perhaps this is due to competition for common signaling pathways that are activated in response to genotoxic stress and to stress related to cytoskeleton structure disturbance. This is indicated by the fact of increased phosphorylation of p53 in the presence of Ptx, which is a typical response to the DNA damage induced by radiation and other genotoxic agents. The antagonism between Ptx and IR in BCap37 (human breast cancer cell line) and KB (human epidermoid carcinoma cell line) cells was observed earlier [38]. There was no synergism between IR and Ptx, instead overall cytotoxicity of these agents significantly decreased. The main reason of this antagonism may be a cell cycle arrest at G2/M caused by IR [38]. In addition antagonism between Ptx and other genotoxic agents - carboplatin and gemcitabine was also observed in human breast Bcap37 and ovarian OV2008 cancer cell lines $[39,40]$.

We have shown that the final effect of the interplay between proapoptotic and antiapoptotic factors as well as cell cycle regulators under the combined action of IR and Ptx is an attenuation of radiation-induced cell death. Thus, Ptx at certain concentrations ( $5 \mathrm{nM}$ in this case) caused protective effect against IR. This effect may be due to inhibition of IR-induced p53 activation by Ptx. It was shown that p53 inhibitors caused radioprotective effect in mice [41].

Ptx-activated caspase-9 in all ATC cells studied indicates the induction of mitochondrial pathway of apoptosis [25]. It is believed that this is the main mechanism of apoptosis induction, more important than the pathway through death receptors and caspase- 8 activation, the latter being carried out only in TP53-positive KTC-2 cell lines [19]. The decrease of Bax expression upon exposure to IR and Ptx seems to be inconsistent with activation of caspases. A possible explanation for this contradiction is the enhanced phosphorylation of antiapoptotic Bcl-2 upon the combined action of Ptx and IR. The Bcl-2 oncoprotein is an inhibitor of apoptosis and is often overexpressed in malignant cells [42, 43]. Phosphorylation of $\mathrm{Bcl}-2$ protein leads to inhibition of its protective, antiapoptotic properties [44], and phosphorylated Bcl-2 also may degrade in proteasomes, as evidenced by decreasing amounts of this protein in ATC cells exposed to Ptx [19].

Differences between the effects of combined action of taxanes and radiation in vitro and in vivo can be explained by several reasons. 1 . The authors used the conventional treatment of tumors. In particular, Ptx was administered to mice at a dose of 10 $\mathrm{mg} / \mathrm{kg} /$ day [28], as a result of which the concentration of the drug in the blood presumably could reach micromolar values (Fig. 3) whereas a clear radioprotective effect was provided by Ptx in a concentration of $5 \mathrm{nM}$. 2. Due to the specificity of the conditions of the existence of tumor cells in the body (microenvironment of the tumor). 3. The duration of the experiment in vitro and in vivo was 1-3 days and 29 days, respectively. And a noticeable effect of treatment was observed only starting from 7 days.

\subsection{Roscovitine}

Compounds that stabilize microtubules, which include taxanes, are effective anticancer drugs. It is known that the therapeutic effect of these drugs is associated with cell cycle arrest, followed by initiation of apoptotic processes [45]. However, the exact 


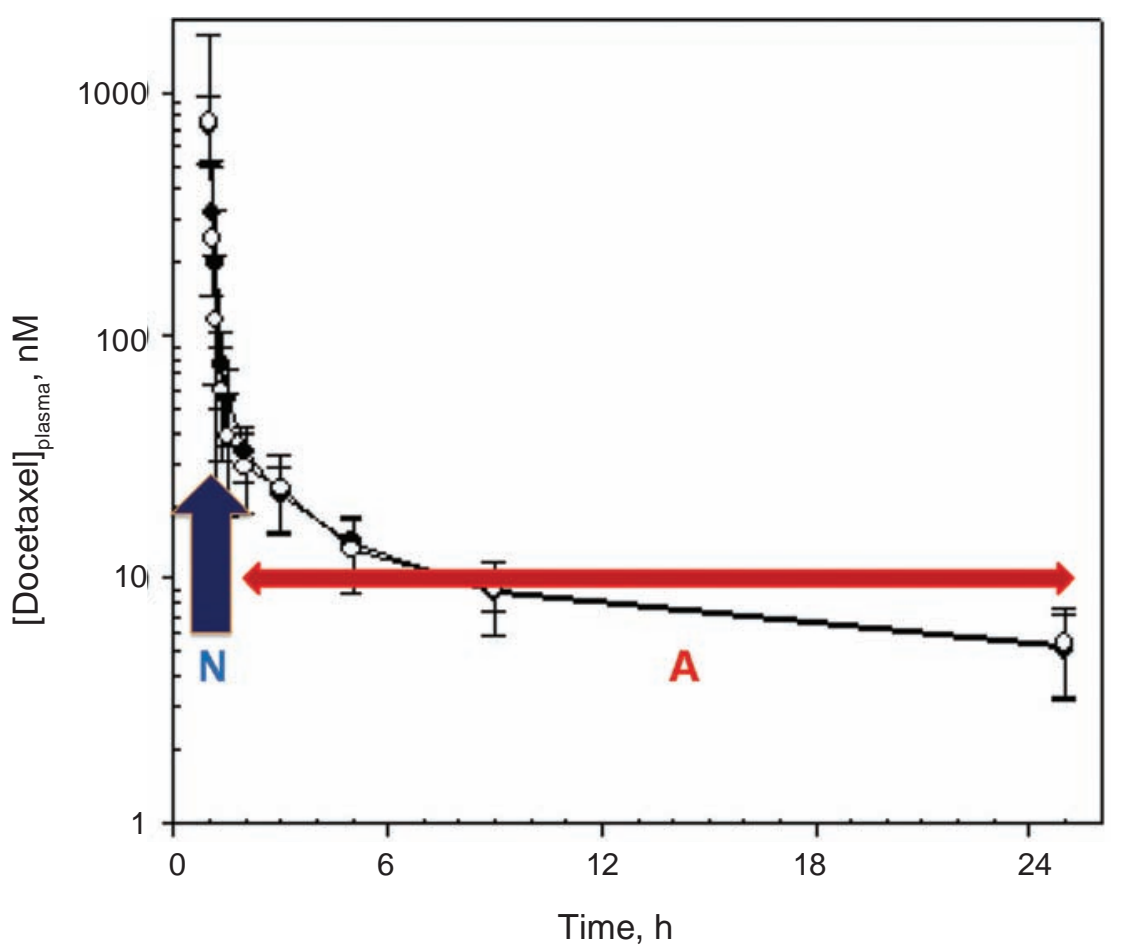

Fig. 3. Dynamics of docetaxel concentration in plasma from the initial $0.8 \mu M$. $N$-concentrations of the drug caused necrosis (800 - 30 nM), A-concentrations caused classic apoptosis (below $30 \mathrm{nM}$ ). Adapted and modified from [69]

mechanism that links cell division impairment with apoptosis induced by drugs is not clear enough.

The mammalian cell cycle is controlled by cyclin-dependent kinases (Cdk), whose activity is modulated by several activators and inhibitors. Cdks are serine/threonine kinases, which play a key role in regulation of both cell cycle and transcription through the phosphorylation of transcription factors and tumor suppressors, involved in DNA replication and cell division [46].

Roscovitine (2, 6, 9-substituted purine analogue; CYC202), inhibits Cdk activity directly by competing for the ATP-binding sites of Cdk and causing apoptosis within various tumor cells [47].

In KTC-2 cells roscovitine showed marked proapoptotic effects, which can be explained by phosphorylation of antiapoptotic protein Bcl-2 and inhibition of cIAP expression [25]. There is also evidence that roscovitine suppressed antiapoptotic Mcl-1 expression and downregulated FLICE-inhibitory proteins in breast cancer cells [48]. Other data show that roscovitine increases the proapoptotic Bax and decreases antiapoptotic survivin and XIAP expression, resulting in caspase-dependent apoptosis of sarcoma cells [49, 50].
It was shown that at Ptx action not c-Jun Nterminal kinase as expected, but cyclin-dependent kinases are responsible for antiapoptotic Bcl-2 phosphorylation [25]. Cdk inhibition enhanced the cytotoxic effects of Ptx at low drug concentrations. There was antagonism between Ptx and roscovitine at higher $(25 \mathrm{nM})$ paclitaxel concentrations. Using of paclitaxel at low (2.5 to $5 \mathrm{nM}$ ) concentrations and roscovitine is a promising combination for further preclinical trials for the development of new therapeutic approaches to the treatment of ATC [25].

\section{3. $N F-\kappa B$ inhibitors}

Experimental data available indicate that Ptx also activates the mechanisms that actively counteract to Ptx-induced apoptosis in ATC cells. Therefore, the development of methods of inactivation of biochemical mechanisms involved in the formation of tumor cells resistance to this anticancer drug is important.

It is generally known that chronic inflammatory processes promote carcinogenesis, enhance aggressiveness, invasiveness of tumors and even can be the cause of malignant transformation of tissue [51]. Nuclear factor NF- $\kappa B$ integrates and distributes 
a multitude of signaling pathways in a cell, and is a key link connecting inflammation with carcinogenesis [52-54]. Family of NF- $\kappa B$ transcription factors is involved in many signaling mechanisms that control the immune response, processes of proliferation, survival, differentiation, apoptosis and migration $[55,56]$. Dysregulation of NF- $\kappa B$ functions leads to inflammation and is associated with serious diseases, including cancer [52, 57]. NF- $\mathrm{kB}$ is constitutively active in most types of cancer, and many signaling pathways involved in carcinogenesis are accompanied by this factor activation $[54,58]$. The possible participation of the chronic inflammation in carcinogenesis of thyroid glands is based on the observation that chronic autoimmune thyroiditis (AIT) is often accompanied by the malignant transformation of thyroid tissue [59]. It is possible that thyroid cancer will develop, if cells with oncogenic mutations coexist in the gland with AIT. The impairment of tissue homeostasis by chronic inflammation can create the conditions for the proliferation of cells carrying the spontaneous mutations [60]. It is also important that the radiation exposure of cells activates NF- $\kappa B$ signaling. Constitutive activation of NF- $\mathrm{KB}$ and significant increase in the amount of mRNA and p65 subunit in thyroid carcinomas in comparison with normal cells, confirm the participation of NF- $\kappa B$ in the genesis of thyroid cancer [61]. Inflammatory process chronically activates NF- $\kappa \mathrm{B}$, which in turn stimulates the expression of cytokines, chemokines, growth factors, and protease cascades, which contribute to the initiation and progression of tumors and provide a niche for malignant transformation [6].

The influence of NF- $\mathrm{KB}$ on apoptotic processes in tumor cells was intensively investigated in the recent years [55]. It was shown that the factor activated a gene family of proteins-inhibitors of apoptosis, which are capable of suppressing the activity of effector caspases, and the caspase- 3 , in the first place [62]. These include cIAP1/2, XIAP, survivin and, besides, these proteins may cause the second wave of NF- $\mathrm{BB}$ activation, thus further enhancing the expression of antiapoptotic genes [63, 64]. Since NF-kB plays an important role in antiapoptotic processes, causes chemo- and radioresistance of tumor cells [55, 65], it was expected that its inhibition would enhance the Ptx toxicity in tumors. Previous data showed that NF- $\kappa B$ suppression with specific inhibitor dehydroxymethylepoxyquinomycin (DHMEQ) enhanced radiation-induced apoptosis in several ATC cell lines [66].
Ptx enhances phosphorylation of I $\mathrm{B} \alpha \boldsymbol{\alpha}$ kinase $(\mathrm{IKK} \alpha)$ and thus activation of NF- $\mathrm{NB}$ in FRO cells. At the same time a decrease of $I \kappa B \alpha$ content [22], due to its phosphorylation by IKK $\alpha$ and degradation of this protein in proteasomes [55], was observed. The amount of p65 (RelA) increased starting from $5 \mathrm{nM}$ of Ptx concentration with maximum at $10 \mathrm{nM}$. Thus, in FRO cells Ptx initiates signaling mechanisms associated with the activation of NF- $\mathrm{\kappa B}$ [22]. It was shown that Pin1 facilitates NF- $\kappa \mathrm{B}$ activation in tumors [67], and perhaps increased expression of this isomerase at low Ptx concentrations (10-25 nM) may contribute to such NF- $\mathrm{KB}$ activation.

Ptx and DHMEQ individually enhance the activation of caspase-3, caspase-9 and PARP cleavage. The combination of both agents demonstrates an additive effect that exceeds the effects of individual compounds [22].

In FRO cells Ptx significantly increases expression of cIAP1, XIAP, survivin and especially cIAP2. Apparently its represents the defense mechanisms in tumor cells opposed the proapoptotic processes induced by Ptx. DHMEQ alone caused significant suppression of these inhibitors expression. Thus, NF- $\kappa B$ controls the expression of apoptosis inhibitors - cIAP1/2, XIAP and survivin in FRO cells. The combined action of Ptx and NF- $\kappa \mathrm{B}$ inhibitor reduced the expression of IAPs that could enhance apoptotic processes in the ATC cells [22].

Signaling systems that counteract the proapoptotic effects of Ptx in the thyroid tumor cells represent PI3K- and MAPK-dependent pathways [19]. Therefore, to clarify the mechanisms that enhance apoptosis in the presence of DHMEQ, activation of MAPK cascade was studied, namely, analyzed phosphorylation of one of the key protein of this cascade - c-Raf-1. Ptx enhances c-Raf-1 phosphorylation. In the presence of DHMEQ, protein phosphorylation attenuated, which indicated the kinase inactivation. Thus, one can conclude that NF- $\mathrm{KB}$ activates MAPK in the FRO cells. It is known that Raf kinase and associated signaling cascade is able to activate NF- $\kappa \mathrm{B}$, especially in tumor cells [68], but the reverse effect of factor on this cascade was studied insufficiently. Since NF- $\kappa \mathrm{B}$ is a transcriptional factor that is able to regulate the expression of a number of antiapoptotic proteins, role of MAPK in these processes remains unclear and requires elucidation. Perhaps MAPK further enhances survival mechanisms through activation of appropriate transcription factors. 
A detailed study of ultralow and low Ptx concentrations showed that the DHMEQ increased the cytotoxic effect of Ptx, but only in rather narrow range of low concentrations of the drug (0.5-5 nM) [22]. We used the cell line with a mutation in the gene encoding I $\mathrm{K} \mathrm{B} \alpha$ resulting in resistance to phosphorylation by IKK $\alpha$, ubiquitinilation and degradation in proteasomes that in turn causes inhibition of NF- $\kappa B$ [66]. It was also shown that Ptx cytotoxicity in the cells with mutated I $\kappa \mathrm{B} \alpha$ increases at low concentrations of the drug.

DHMEQ itself in vivo just inhibited the tumor growth, while Ptx significantly reduced tumor volume compared to untreated mice. A combination of both compounds was even more effective - tumors completely regressed after the 16th day of treatment [22].

Thus, low doses of Ptx can be used in further preclinical and clinical studies together with inhibitors of NF- $\mathrm{kB}$ signaling pathway.

\section{Concluding remarks}

The taxanes in concentrations starting from 1-2 $\mathrm{nM}$ are effective in the ATC cells. It should be noted that the drug concentrations in the range of 1-30 nM cause apoptosis, whereas higher concentrations lead to cell cycle arrest and necrotic processes [21]. Apoptosis needs cell cycle transition, whereas necrosis occurs at cell cycle arrest.

The pharmacokinetics study of docetaxel showed that in an hour plasma concentration of the drug dropped from the initial $0.8 \mu \mathrm{M}$ to $100 \mathrm{nM}$, and in 2-3 h - to $30 \mathrm{nM}$ (Fig. 3) [69]. Consequently, 90$95 \%$ of taxanes during 1-2 hours is metabolized and excreted from the body without a therapeutic effect on the tumor, but having a significant toxic effect on the liver, kidneys and other normal tissues and organs.

According to the theory of "wounds that do not heal" [70-72] it is essential for anticancer drugs to cause not necrosis but apoptosis in the tumor. Necrosis stimulates angiogenesis, supplying tumor with growth factors (VEGF in the first place), nutrients, cytokines, and hence enhances its regeneration and growth. Therefore, very high drug concentrations used in clinic may not necessarily be the best treatment strategy. The average actual effective concentration of taxanes in plasma for the periods from 3 to $24 \mathrm{~h}$ is around $10 \mathrm{nM}$ (Fig. 3). Based on these observations, one might suggest that optimized treatment would employ a protracted (e. g. 1-2 weeks) regimen of drug administration aimed at attaining low drug concentrations (1-30 nM) in the circulation. Presumably, such modality could be sufficient to induce massive apoptosis of ATC cells and thus provide in a better chance to control the disease.

It should be noted that relatively low Ptx concentrations appeared to be effective with no further decrease in cell survival starting from 10-25 nM (Fig. 2). These results may have some practical importance, because clinically significant concentrations of Ptx are considered up to $50 \mu \mathrm{M}[69,73]$. Recent studies indicate the promise of so-called metronomic chemotherapy, where ultra-low pico- and even femtomolar concentrations of taxanes are used, which reduce the activity of endothelial cells and thus inhibit angiogenesis in tumor tissue [74, 75].

The combination of paclitaxel and NF- $\kappa \mathrm{B}$ inhibitor, IR, roscovitine is a promising option for preclinical studies on the treatment of invasive and radioiodine-resistant forms of thyroid cancer. However, in this case it is also necessary to take into account the concentration of taxanes. Experiments on ATC cells show that combination with roscovitine and NF- $\mathrm{KB}$ inhibitor is effective only within narrow range of low concentrations of taxanes.

Although the traditional therapy of ATC in vivo with the use of taxanes and IR has turned out to be encouraging [28], it is necessary to seek new treatment options, varying the concentration and dosage of both agents. And with combined use of taxanes and IR it is necessary to take into account that certain concentrations of taxanes can have a radioprotective effect. With regard to the radiation treatment, the most effective is the use of low fractionated doses ( $0.5 \mathrm{~Gy})$, which may cause the effect of hypersensitivity of tumor cells [76] instead of the high doses (20-80 Gy) used in clinics.

Perhaps the most promising may be the combination of taxanes with agents that destroy cancer stem cells, such as hypoglycemic and nontoxic drug metformin [77].

Priorities for future research can be designated as the search for effective combinations of antimitotic compounds (e.g. taxanes) with genotoxic agents, specific inhibitors of signaling cascades, mediating resistance to antimitotics, with inhibitors of the multidrug resistance genes (Mdr) and their products, with other inhibitors and agonists that were indicated. Such a complex effect on the tumor cell will increase the effectiveness of the action of antimitotic compounds and reduce their concentrations and toxicity (Fig. 4). 


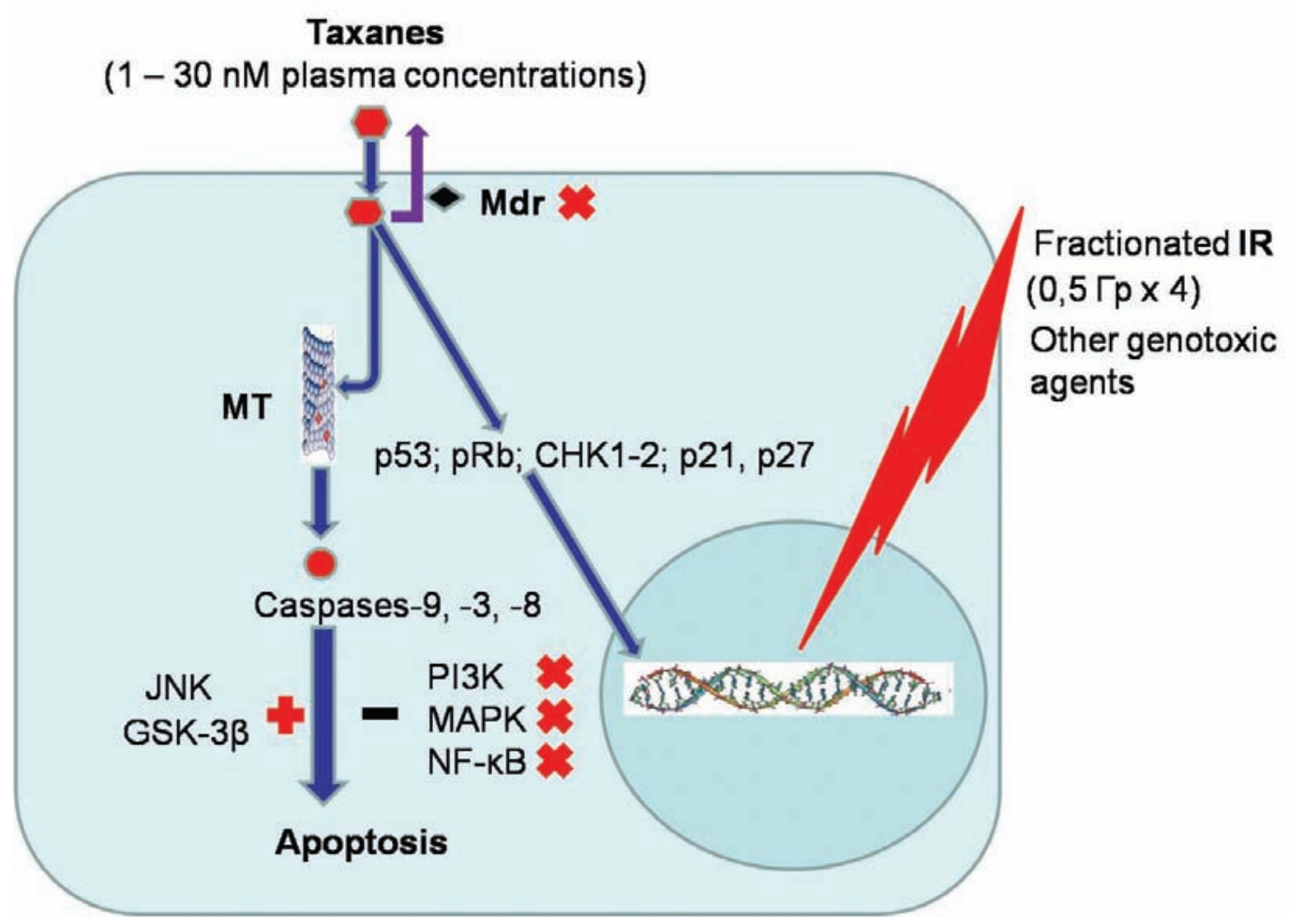

Fig. 4. Scheme of complex treatment of ATC. Combined using of low doses of taxanes and genotoxic agents on the background of inhibition: Mdr-transporters, PI3K, Raf/MEK/ERK1/2, NF- $\kappa B$ signaling pathways. MT microtubules, IR - ionizing radiation, Mdr - multiple drug resistance ATP-binding cassette transporters. Other designations in the text

\section{БІОХІМІЧНІ АСПЕКТИ \\ КОМБІНОВАНОГО ЗАСТОСУВАННЯ \\ ТАКСАНІВ, ОПРОМІНЕННЯ ТА \\ ІНШИХ АНТИНЕОПЛАСТИЧНИХ \\ АГЕНТІВ ДЛЯ ЛІКУВАННЯ \\ АНАПЛАСТИЧНОЇ КАРЦИНОМИ \\ ЩИТОПОДІБНОї ЗАЛОЗИ}

В. М. Пушкарьов ${ }^{凶}$, О. I. Ковзун,

В. В. Пушкарьов, Б. Б. Гуда, М. Д. Тронько

ДУ «Інститут ендокринології та обміну речовин

ім. В. П. Комісаренка НАМН України», Київ; e-mail: pushkarev.vm@gmail.com

В огляді підсумовуються результати циклу власних досліджень і дані літератури щодо біохімічних механізмів комбінованого впливу таксанів з $\gamma$-опроміненням та іншими протипух- линними агентами на один з найагресивніших типів раку людини - анапластичну карциному щитоподібної залози. Обговорюються антагоністичні взаємодії між таксанами i радіацією на рівні апоптотичних механізмів $\mathrm{i}$ регуляторів клітинного циклу. Обгрунтовується ефективність і перспективність використання низьких концентрацій таксанів і низьких доз фракційного $\gamma$-опромінення. Приділяється увага ролі запалення і його ключового фактора NF-кB у генезі карцином щитоподібної залози та за їх лікування. Окреслено напрями подальших досліджень.

К л ю ч о в і с л о в а:анапластичнакарцинома щитоподібної залози, таксани, $\gamma$-опромінення, клітинний цикл, росковітин, NF-кB, апоптоз. 


\section{БИОХИМИЧЕСКИЕ АСПЕКТЫ КОМБИНИРОВАННОГО ПРИМЕНЕНИЯ ТАКСАНОВ, ОБЛУЧЕНИЯ И ДРУГИХ АНТИНЕОПЛАСТИЧЕСКИХ АГЕНТОВ ДЛЯ ЛЕЧЕНИЯ АНАПЛАСТИЧЕСКОЙ КАРЦИНОМЫ ЩИТОВИДНОЙ ЖЕЛЕЗЫ}

B. М. Пушкарёв ${ }^{\bowtie}$, Е. И. Ковзун, В. В. Пушкарёв, Б. Б. Гуда, Н. Д. Тронько

ГУ «Институт эндокринологии и обмена веществ им. В. П. Комисаренко НАМН Украины», Киев; e-mail: pushkarev.vm@gmail.com

В обзоре суммируются итоги цикла собственных исследований и данные литературы по биохимическим механизмам комбинированного воздействия таксанов с $\gamma$-облучением и другими противоопухолевыми агентами на один из наиболее агрессивных типов рака человека - анапластическую карциному щитовидной железы. Обсуждаются антагонистические взаимодействия между таксанами и радиацией на уровне апоптотических механизмов и регуляторов клеточного цикла. Обосновывается эффективность и перспективность использования низких концентраций таксанов и низких доз фракционного $\gamma$-облучения. Уделяется внимание роли воспаления и его ключевого фактора NF-кB в генезе карцином щитовидной железы и их лечении. Очерчены направления дальнейших исследований.

К л ю че в е с ло в а: анапластическая карцинома щитовидной железы, таксаны, $\gamma$-облучение, клеточный цикл, росковитин, NF-кB, апоптоз.

\section{References}

1. Tronko MD, Pushkarev VV, Kovzun OI, Pushkarev VM. Anaplastic carcinoma of the thyroid gland: new approaches for its treatment (review). Endokrynologia. 2013; 18(2): 78-91. (In Ukrainian).

2. Penna GC, Vaisman F, Vaisman M, SobrinhoSimões M, Soares P. Molecular markers involved in tumorigenesis of thyroid carcinoma: focus on aggressive histotypes. Cytogenet Genome Res. 2016; 150(3-4): 194-207.
3. Tiedje V, Stuschke M, Weber F, Dralle H, Moss L, Führer D. Anaplastic thyroid carcinoma: review of treatment protocols. Endocr Relat Cancer. 2018; 25(3): R153-R161.

4. Lin RY. Thyroid cancer stem cells. Nat Rev Endocrinol. 2011; 7(10): 609-616.

5. Molinaro E, Romei C, Biagini A, Sabini E, Agate L, Mazzeo S, Materazzi G, SellariFranceschini S, Ribechini A, Torregrossa L, Basolo F, Vitti P, Elisei R. Anaplastic thyroid carcinoma: from clinicopathology to genetics and advanced therapies. Nat Rev Endocrinol. 2017; 13(11): 644-660.

6. Tronko ND, Pushkarev VM. Thirty years after the Chernobyl accident: molecular genetic mechanisms of carcinogenesis of the thyroid gland. CytolGenet. 2016; 50(6): 366-371.

7. Cancer Genome Atlas Research Network. Integrated genomic characterization of papillary thyroid carcinoma. Cell. 2014; 159(3): 676-690.

8. Xing M. Molecular pathogenesis and mechanisms of thyroid cancer. Nat Rev Cancer. 2013; 13(3): 184-199.

9. Charles RP, Silva J, Iezza G, Phillips WA, McMahon M. Activating BRAF and PIK3CA mutations cooperate to promote anaplastic thyroid carcinogenesis. Mol Cancer Res. 2014; 12(7): 979-986.

10. Takano T. Fetal cell carcinogenesis of the thyroid: a modified theory based on recent evidence. Endocr J. 2014; 61(4): 311-320.

11. Guo Z, Hardin H, Lloyd RV. Cancer stem-like cells and thyroid cancer. Endocr Relat Cancer. 2014; 21(5): T285-T300.

12. Hardin H, Zhang R, Helein H, Buehler D, Guo Z, Lloyd RV. The evolving concept of cancer stemlike cells in thyroid cancer and other solid tumors. Lab Invest. 2017; 97(10): 1142-1151.

13. Takano T. Fetal cell carcinogenesis of the thyroid: theory and practice. Semin Cancer Biol. 2007; 17(3): 233-240.

14. Kunstman JW, Juhlin CC, Goh G, Brown TC, Stenman A, Healy JM, Rubinstein JC, Choi M, Kiss N, Nelson-Williams C, Mane S, Rimm DL, Prasad ML, Höög A, Zedenius J, Larsson C, Korah R, Lifton RP, Carling T. Characterization of the mutational landscape of anaplastic thyroid cancer via whole-exome sequencing. Hum $\mathrm{Mol}$ Genet. 2015; 24(8): 2318-2329. 
15. Nikiforov YE. Thyroid cancer in 2015: Molecular landscape of thyroid cancer continues to be deciphered. Nat Rev Endocrinol. 2016; 12(2): 67-68.

16. Xu B, Ghossein R. Genomic landscape of poorly differentiated and anaplastic thyroid carcinoma. Endocr Pathol. 2016; 27(3): 205-212.

17. Landa I, Ibrahimpasic T, Boucai L, Sinha R, Knauf JA, Shah RH, Dogan S, RicarteFilho JC, Krishnamoorthy GP, Xu B, Schultz N, Berger MF, Sander C, Taylor BS, Ghossein R, Ganly I, Fagin JA. Genomic and transcriptomic hallmarks of poorly differentiated and anaplastic thyroid cancers. J Clin Invest. 2016; 126: 10521066.

18. Gild ML, Bullock M, Robinson BG, CliftonBligh R. Multikinase inhibitors: a new option for the treatment of thyroid cancer. Nat Rev Endocrinol. 2011; 7(10): 617-624.

19. Pushkarev VM, Starenki DV, Saenko VA, Namba H, Kurebayashi J, Tronko MD, Yamashita S. Molecular mechanisms of the effects of low concentrations of taxol in anaplastic thyroid cancer cells. Endocrinology. 2004; 145(7): 3143-3152.

20. Ojima I, Lichtenthal B, Lee S, Wang C, Wang X. Taxane anticancer agents: a patent perspective. Expert Opin Ther Pat. 2016; 26(1): 1-20.

21. Pushkarev VM, Starenki DV, Saenko VA, Yamashita S, Kovzun OI, Popadiuk ID, Pushkarev VV, Tronko MD. Effects of low and high concentrations of antitumour drug taxol in anaplastic thyroid cancer cells. Exp Oncol. 2009; 31(1): 16-21.

22. Pushkarev VV, Starenki DV, Pushkarev VM, Kovzun OI, Tronko MD. Inhibitor of the transcription factor NF- $\kappa \mathrm{B}$, DHMEQ, enhances the effect of paclitaxel on cells of anaplastic thyroid carcinoma in vitro and in vivo. $U k r$ Biochem J. 2015; 87(3): 63-74.

23. Mitra A, Sept D. Taxol allosterically alters the dynamics of the tubulin dimer and increases the flexibility of microtubules. Biophys J. 2008; 95(7): 3252-3258.

24. Pushkarev VM, Starenki DV, Saenko VA, Pushkarev VV, Kovzun OI, Tronko MD, Popadiuk ID, Yamashita S. Differential effects of low and high doses of Taxol in anaplastic thyroid cancer cells: possible implication of the Pin1 prolyl isomerase. Exp Oncol. 2008; 30(3): 190-194.
25. Pushkarev VV, Kovzun OI, Pushkarev VM, Tronko MD. The effect of the combined action of roscovitine and Paclitaxel on the apoptotic and cell cycle regulatory mechanisms in colon and anaplastic thyroid cancer cells. ISRN Biochem. 2012; 2012: 826305.

26. Spring PM, Arnold SM, Shajahan S, Brown B, Dey S, Lele SM, Valentino J, Jones R, Mohiuddin M, Ahmed MM. Low dose fractionated radiation potentiates the effects of taxotere in nude mice xenografts of squamous cell carcinoma of head and neck. Cell Cycle. 2004; 3(4): 479-485.

27. Toiyama Y, Inoue Y, Hiro J, Ojima E, Watanabe H, Narita Y, Hosono A, Miki C, Kusunoki M. The range of optimal concentration and mechanisms of paclitaxel in radio-enhancement in gastrointestinal cancer cell lines. Cancer Chemother Pharmacol. 2007; 59(6): 733-742.

28. Pushkarev VM, Starenki DV, Saenko VO, Tronko MD, Yamashita S. Effects of Paclitaxel and combination of the drug with radiation therapy in an in vivo model of anaplastic thyroid carcinoma. Exp Oncol. 2011; 33(1): 24-27.

29. Pushkarev VM, Kovzun OI, Pushkarev VV, Tronko MD. Biochemical effects of combined action of gamma-irradiation and paclitaxel on anaplastic thyroid cancer cells. Ukr Biokhim Zhurn. 2013; 85(1): 51-61.

30. Choy H. Chemoradiation in cancer therapy. Springer Science \& Business Media, 2002. $420 \mathrm{p}$.

31. Peña-Blanco A, García-Sáez AJ. Bax, Bak and beyond - mitochondrial performance in apoptosis. FEBS J. 2018; 285(3): 416-431.

32. Zuckerman V, Lenos K, Popowicz GM, Silberman I, Grossman T, Marine JC, Holak TA, Jochemsen AG, Haupt Y. c-Abl phosphorylates Hdmx and regulates its interaction with p53. J Biol Chem. 2009; 284(6): 4031-4039.

33. Waning DL, Lehman JA, Batuello CN, Mayo LD. c-Abl phosphorylation of Mdm2 facilitates Mdm2-Mdmx complex formation. $J$ Biol Chem. 2011; 286(1): 216-222.

34. Nehmé A, Lee BL, Baskaran R, Zhang Q, Lin X, Christen RD. Effect of c-Abl tyrosine kinase on the cellular response to paclitaxel-induced microtubule damage. Br J Cancer. 2000; 83(10): 1360-1366.

35. Stracker TH, Usui T, Petrini JH. Taking the time to make important decisions: the checkpoint 
effector kinases Chk1 and Chk2 and the DNA damage response. DNA Repair (Amst). 2009; 8(9): 1047-1054.

36. Wong JV, Dong P, Nevins JR, Mathey-Prevot B, You L. Network calisthenics: control of E2F dynamics in cell cycle entry. Cell Cycle. 2011; 10(18): 3086-3094.

37. Wang X, Zeng L, Wang J, Chau JF, Lai KP, Jia D, Poonepalli A, Hande MP, Liu H, He G, He L, Li B. A positive role for C-Abl in Atm and Atr activation in DNA damage response. Cell Death Differ. 2011; 18(1): 5-15.

38. Sui M, Dziadyk JM, Zhu X, Fan W. Cell cycledependent antagonistic interactions between paclitaxel and gamma-radiation in combination therapy. Clin Cancer Res. 2004; 10(14): 48484857.

39. Sui M, Xiong X, Kraft AS, Fan W. Combination of gemcitabine antagonizes antitumor activity of paclitaxel through prevention of mitotic arrest and apoptosis. Cancer Biol Ther. 2006; 5(8): 1015-1021.

40. Xiong X, Sui M, Fan W, Kraft AS. Cell cycle dependent antagonistic interactions between paclitaxel and carboplatin in combination therapy. Cancer Biol Ther. 2007; 6(7): 10671073.

41. Strom E, Sathe S, Komarov PG, Chernova OB, Pavlovska I, Shyshynova I, Bosykh DA, Burdelya LG, Macklis RM, Skaliter R, Komarova EA, Gudkov AV. Small-molecule inhibitor of p53 binding to mitochondria protects mice from gamma radiation. Nat Chem Biol. 2006; 2(9): 474-479.

42. Chipuk JE, Moldoveanu T, Llambi F, Parsons MJ, Green DR. The BCL-2 family reunion. Mol Cell. 2010; 37(3): 299-310.

43. Su J, Zhou L, Xia MH, Xu Y, Xiang XY, Sun LK. $\mathrm{Bcl}-2$ family proteins are involved in the signal crosstalk between endoplasmic reticulum stress and mitochondrial dysfunction in tumor chemotherapy resistance. Biomed Res Int. 2014; 2014: 234370.

44. Geng F, Tang L, Li Y, Yang L, Choi KS, Kazim AL, Zhang Y. Allyl isothiocyanate arrests cancer cells in mitosis, and mitotic arrest in turn leads to apoptosis via $\mathrm{Bcl}-2$ protein phosphorylation. J Biol Chem. 2011; 286(37): 32259-32267.

45. Bergstralh DT, Ting JP. Microtubule stabilizing agents: their molecular signaling consequences and the potential for enhancement by drug combination. Cancer Treat Rev. 2006; 32(3): 166-179.

46. Malumbres M. Cyclin-dependent kinases. Genome Biol. 2014; 15(6): 122.

47. Cicenas J, Kalyan K, Sorokinas A, Stankunas E, Levy J, Meskinyte I, Stankevicius V, Kaupinis A, Valius M. Roscovitine in cancer and other diseases. Ann Transl Med. 2015; 3(10): 135.

48. Ortiz-Ferrón G, Yerbes R, Eramo A, LópezPérez AI, De Maria R, López-Rivas A. Roscovitine sensitizes breast cancer cells to TRAIL-induced apoptosis through a pleiotropic mechanism. Cell Res. 2008; 18(6): 664-676.

49. Cui C, Wang Y, Wang Y, Zhao M, Peng S. Exploring the relationship between the inhibition selectivity and the apoptosis of roscovitinetreated cancer cells. J Anal Methods Chem. 2013; 2013: 389390.

50. Bai J, Li Y, Zhang G. Cell cycle regulation and anticancer drug discovery. Cancer Biol Med. 2017; 14(4): 348-362.

51. Pushkarev VM, Kovzun OI, Pushkarev VV, Huda BB, Tronko ND. Chronic inflammation and cancer. Role of nuclear factor NF- $\mathrm{BB}$. Zhurn Nat Acad Med Nauk Ukraine. 2015; 21(3-4): 287298. (In Ukrainian).

52. Karin M. NF-kappaB as a critical link between inflammation and cancer. Cold Spring Harb Perspect Biol. 2009; 1(5): a000141.

53. Blaylock RL. Cancer microenvironment, inflammation and cancer stem cells: A hypothesis for a paradigm change and new targets in cancer control. Surg Neurol Int. 2015; 6: 92.

54. Riedlinger T, Haas J, Busch J, van de Sluis B, Kracht M, Schmitz ML. The direct and indirect roles of NF- $\kappa \mathrm{B}$ in cancer: lessons from oncogenic fusion proteins and knock-in mice. Biomedicines. 2018; 6(1). pii: E36.

55. Hayden MS, Ghosh S. NF- $\kappa$ B, the first quartercentury: remarkable progress and outstanding questions. Genes Dev. 2012; 26(3): 203-234.

56. Bauerle KT, Schweppe RE, Lund G, Kotnis G, Deep G, Agarwal R, Pozdeyev N, Wood WM, Haugen BR. Nuclear factor $\kappa B$-dependent regulation of angiogenesis, and metastasis in an in vivo model of thyroid cancer is associated with secreted interleukin-8. J Clin Endocrinol Metab. 2014; 99(8): E1436-E1444. 
57. Ben-Neriah Y, Karin M. Inflammation meets cancer, with NF- $\kappa \mathrm{B}$ as the matchmaker. Nat Immunol. 2011; 12(8): 715-723.

58. Nagel D, Vincendeau M, Eitelhuber AC, Krappmann D. Mechanisms and consequences of constitutive NF- $\kappa \mathrm{B}$ activation in B-cell lymphoid malignancies. Oncogene. 2014; 33(50): 5655-5665.

59. Muzza M, Degl'Innocenti D, Colombo C, Perrino M, Ravasi E, Rossi S, Cirello V, BeckPeccoz P, Borrello MG, Fugazzola L. The tight relationship between papillary thyroid cancer, autoimmunity and inflammation: clinical and molecular studies. Clin Endocrinol (Oxf). 2010; 72(5): 702-708.

60. Guarino V, Castellone MD, Avilla E, Melillo RM. Thyroid cancer and inflammation. Mol Cell Endocrinol. 2010; 321(1): 94-102.

61. Li X, Abdel-Mageed AB, Mondal D, Kandil E. The nuclear factor kappa-B signaling pathway as a therapeutic target against thyroid cancers. Thyroid. 2013; 23(2): 209-218.

62. Altieri DC. Survivin and IAP proteins in celldeath mechanisms. Biochem J. 2010; 430(2): 199-205.

63. Winsauer G, Resch U, Hofer-Warbinek R, Schichl YM, de Martin R. XIAP regulates biphasic NF-kappaB induction involving physical interaction and ubiquitination of MEKK2. Cell Signal. 2008; 20(11): 2107-2112.

64. Gyrd-Hansen M, Meier P. IAPs: from caspase inhibitors to modulators of NF-kappaB, inflammation and cancer. Nat Rev Cancer. 2010; 10(8): 561-574.

65. Li F, Sethi G. Targeting transcription factor NF-kappaB to overcome chemoresistance and radioresistance in cancer therapy. Biochim Biophys Acta. 2010; 1805(2): 167-180.

66. Starenki D, Namba H, Saenko V, Ohtsuru A, Yamashita S. Inhibition of nuclear factor-kappaB cascade potentiates the effect of a combination treatment of anaplastic thyroid cancer cells. J Clin Endocrinol Metab. 2004; 89(1): 410-418.

67. Shinoda K, Kuboki S, Shimizu H, Ohtsuka M, Kato A, Yoshitomi H, Furukawa K, Miyazaki M. Pin1 facilitates NF- $\mathrm{BB}$ activation and promotes tumour progression in human hepatocellular carcinoma. Br J Cancer. 2015; 113(9): 1323-1331.
68. Zhu CX, Li WZ, Guo YL, Chen L, Li GH, Yu JJ, Shu B, Peng S. Tumor suppressor RKIP inhibits prostate cancer cell metastasis and sensitizes prostate cancer cells to docetaxel treatment. Neoplasma. 2018; 65(2): 228-233.

69. Witta SE, Gustafson DL, Pierson AS, Menter A, Holden SN, Basche M, Persky M, O'Bryant CL, Zeng C, Baron A, Long ME, Gibbs A, Kelly K, Bunn PA Jr, Chan DC, Pallansch P, Eckhardt SG. A phase I and pharmacokinetic study of exisulind and docetaxel in patients with advanced solid tumors. Clin Cancer Res. 2004; 10(21): 7229-7237.

70. Luchnik AN. A common link in the mechanism of the self-maintenance of malignant growth: the syndrome of the nonhealing wound. Ontogenez. 2000; 31(3): 227-231. (In Russian).

71. Ribatti D, Tamma R. A revisited concept. Tumors: Wounds that do not heal. Crit Rev Oncol Hematol. 2018; 128: 65-69.

72. Dvorak HF. Tumors: wounds that do not healredux. Cancer Immunol Res. 2015; 3(1): 1-11.

73. Piñeiro D, Martín ME, Guerra N, Salinas M, González VM. Calpain inhibition stimulates caspase-dependent apoptosis induced by taxol in NIH3T3 cells. Exp Cell Res. 2007; 313(2): 369379.

74. Maiti R. Metronomic chemotherapy. J Pharmacol Pharmacother. 2014;5(3): 186-192.

75. Kerbel RS, Shaked Y. The potential clinical promise of 'multimodality' metronomic chemotherapy revealed by preclinical studies of metastatic disease. Cancer Lett. 2017; 400: 293304.

76. Gupta S, Koru-Sengul T, Arnold SM, Devi GR, Mohiuddin M, Ahmed MM. Low-dose fractionated radiation potentiates the effects of cisplatin independent of the hyper-radiation sensitivity in human lung cancer cells. Mol Cancer Ther. 2011; 10(2): 292-302.

77. Pushkarev VM, Sokolova LK, Pushkarev VV, Tronko MD. Biochemical mechanisms connecting diabetes and cancer. Effects of methormine. Endokrynologia. 2018; 23(2):167179. (In Russian).

Received 05.04.2018 